\title{
Research Note \\ Molecular and phylogenetic identification of an oil- producing strain of Nannochloropsis oceanica (Eustigmatophyceae) isolated from the southwestern Atlantic coast (Argentina)
}

Identificación molecular y filogenética de una cepa oleaginosa de Nannochloropsis oceanica

(Eustigmatophyceae) aislada de la costa Atlántica suroeste (Argentina)

\section{Natalia Bongiovani ${ }^{1}$, M. Virginia Sanchez-Puerta ${ }^{2}$, Cecilia Popovich $^{1,3}$ and Patricia Leonardi ${ }^{1,3}$}

\begin{abstract}
${ }^{1}$ Laboratorio de Estudios Básicos y Biotecnológicos en Algas y Hongos (LEBBAH), Centro de Recursos Naturales Renovables de la Zona Semiárida (CERZOS) -CONICET, Camino La Carrindanga, Km 7, 8000, Bahía Blanca, Argentina ${ }^{2}$ IBAM-CONICET, Instituto de Ciencias Básicas, Facultad de Ciencias Agrarias, Universidad Nacional de Cuyo, Alte. Brown 500, 5505, Chacras de Coria, Mendoza, Argentina. mvsanchezpuerta@ fca.uncu.edu.ar ${ }^{3}$ Laboratorio de Ficología y Micología, Departamento de Biología, Bioquímica y Farmacia, Universidad Nacional del Sur, San Juan 670, 8000, Bahía Blanca, Argentina
\end{abstract}

Abstract.- Screening of local microalgae species with potential for oil production is essential to achieve successful commercial large-scale cultures. In this study, identification of a South American species of Nannochloropsis was carried out using molecular and phylogenetic analyses of chloroplastic and nuclear genes, $r c b L$ and $18 \mathrm{~S}$ rDNA, respectively. The gene sequences for the studied strain were highly similar to other strains of Nannochloropsis oceanica (100\% for $18 \mathrm{~S}$ rDNA and $99.7 \%$ for $\mathrm{rbcL}$ ) isolated from the Red Sea or Mediterranean Sea (Israel) and from the Pacific Ocean (Japan).

Key words: Nannochloropsis oceanica, rcbL, 18S rDNA, oil

\section{INTRODUCTION}

The decrease in fossil fuel reserves, as well as a sharp increase in oil prices, has intensified the search for alternative renewable energy sources. This concern has promoted a special interest in developing third-generation biofuels, which are produced from renewable feedstock, such as algal biomass, and in particular biodiesel from microalgal lipids (Pruvost 2011). For sustainable production of algal-derived biodiesel, exploitation of local microalgae is advantageous. However, the appropriate selection of fast-growing, lipid-producing microalgae strains that are adapted to local climatic conditions constitutes one of the major challenges faced by researchers worldwide. The first step in these studies includes species selection, which is essential for a reliable analysis. In turn, this requires recognizing the diagnostic characteristics of different microalgal groups to achieve a correct identification (Leonardi et al. 2011). Traditionally, light microscopy and transmission electron microscopy were standard procedures for identification and characterization of microalgae species. Nevertheless, these methods were not sufficient for accurate species identification in several algal lineages (Karlson et al. 1996).
The genus Nannochloropsis comprises 6 species: $N$. oculata (Droop) Hibberd (Hibberd 1981), N. salina Hibberd (Hibberd 1981), N. gaditana Lubian (Lubian 1982), N. granulata Karlson \& Potter (Karlson et al. 1996), N. limnetica (Krienitz et al. 2000) and N. oceanica (Suda et al. 2002). Taxonomic identification of Nannochloropsis species is challenging due to the small cell size and simple structure (Maruyama et al. 1986, Gladu et al. 1995), the difficulties in fixing the cells for transmission electron microscopy (Hibberd 1981) and the lack of sexual reproduction. Even though meiosis-related genes were found in the genome of $N$. gaditana, no transcripts were detected (Radakovits et al. 2012).

Some species of Nannochloropsis, such as Nannochloropsis sp. (Sukenik et al. 1989), N. oculata (Renaud et al. 1991, Li et al. 2009) and N. gaditana (Ferreira et al. 2009) are used in marine aquaculture as an important source of eicosapentaenoic acid. Moreover, different species of Nannochloropsis have recently been considered appealing feedstock for biodiesel production due to their ability to accumulate high amounts of lipids. 
For example, Nannochloropsis sp. (Rodolfi et al. 2009, Pal et al. 2011, Bondioli et al. 2012), N. gaditana (Simionato et al. 2011, 2013), N. oculata (Van Vooren et al. 2012), N. salina (Sforza et al. 2012) and N. oceanica (Dong et al. 2013, Pal et al. 2013, Bongiovani et al. 2013, Solovchenko et al. 2014). Given the importance of Nannochloropsis as an oleaginous species for biodiesel production, a number of genomic and transcriptomic studies on several species of the genus have been recently published (Radakovits et al. 2012, Vieler et al. 2012, Wei et al. 2013, Starkenburg et al. 2014, Wang et al. 2014, Carpinelli et al. 2013, Hu et al. 2014, Li et al. 2014).

Because the ability to produce large quantities of lipids is species-specific (Hu et al. 2008), a correct specific identification is critical. Thus, the phylogenetic species concept becomes particularly useful (Andersen et al. 1998). Species of Nannochloropsis have been delimited by DNA sequence analysis (Fawley \& Fawley 2007) based on nuclear (18S rDNA) and chloroplastic $(r b c L)$ markers and sets of orthogonal genes (Krienitz et al. 1996, Andersen et al. 1998, Suda et al. 2002, Vieler et al. 2012, Cao et al. 2013, Wang et al. 2014).

In this study, we identified a new strain of Nannochloropsis oceanica CCALA 978 based on molecular taxonomy and studied its evolutionary relationships based on phylogenetic analyses with nuclear and chloroplastic genes. Recent studies have demonstrated the potential suitability of this strain isolated from the southwestern Atlantic coast for biodiesel production (Bongiovani et al. 2013; Bongoviani et al. 2013²).

\section{Materials ANd Methods}

\section{STrain AND CUlture CONDITIONS}

Nannochloropsis oceanica (CCALA 978, Culture Collection of Autotrophic Organism, Institute of Botany, Academy of Sciences of the Czech Republic) was isolated from the southwestern Atlantic coast $\left(65^{\circ} 01^{\prime} \mathrm{W}, 43^{\circ} 18^{\prime} \mathrm{S}\right.$, Argentina) and kindly provided by CRIAR, Instituto de Biología Marina y Pesquera Almirante Storni, San Antonio Oeste, Río Negro province, Argentina. This species was cultured in f/2 marine medium (Guillard 1973). Cultures were maintained in flasks under the following

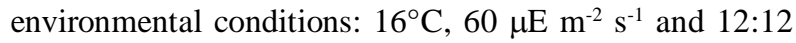
light:dark period. Cultures were continuously bubbled with air; $1-2 \% \mathrm{CO}_{2}$ was mixed in the air stream and this mixture was applied during 3-4 h per day.

\section{Molecular analysis}

DNA EXTRACTION AND SEQUENCING

Approximately $1 \mathrm{~L}$ of culture was harvested by centrifugation, flash-frozen in liquid nitrogen and stored at $-80^{\circ} \mathrm{C}$. Genomic DNA was extracted using Illustra Nucleon Phytopure Genomic DNA extraction kit (GE Healthecare, Buckinghamshire, UK) and kept at $-20^{\circ} \mathrm{C}$ until analysis.

The nuclear-encoded 18S small subunit (SSU) rDNA and the chloroplast-encoded $r b c L$ genes were amplified using the following published primers: for $r b c L$, rbcLF: 5'GATGCAAACTACACAATTAAAGATACTG3' and rbcLR: 5'ATTTTGTTCGTTTGTTAAATCCG3' (Li et al. 2011); and for 18S rDNA, 18SrDNAF: 5'CAAGTTTC TGCCCTATCAGCT3' and 18S rDNAR: 5'GCTTTCG CAGTAGTTCGTCTT3' (Li et al. 2011), NS3a: 5'GCAAGT CTGGTGCCAGCAGCC3' (Fawley et al. 2005), Primer A: 5'CCGAATTCGTCGACAACCTGGTTGATCCTGCCAGT3' (Medlin et al. 1988) and Primer B: 5'CCCGGGATCCA AGCTTGATCCTTCTGCAGGTTCACCTAC3' (Medlin $e t$ al. 1988). Amplification products were sequenced by Sanger sequencing with Applied Biosystems 3730XL (Life Technologies) and sequences were deposited in GenBank (accession numbers KF010153 and KF010154 for $r b c L$ and $18 \mathrm{~S}$ rDNA, respectively). Sequences were aligned using MEGA 5.1 (Tamura et al. 2011). GenBank accession numbers and taxonomic data of Nannochloropsis species included in the $r b c L$ and $18 \mathrm{~S}$ rDNA alignments are listed in Table 1.

\section{Phylogenetic analyses}

Phylogenetic analyses were performed separately for each data set. Maximum Parsimony (MP) analyses were done with PAUP*4b10 (Swofford et al. 2002). For MP analyses, characters were unweighted and a heuristic search was used with the tree bisection and reconnection (TBR) branch-swapping method, and addition was random with 10 repetitions. JModeltest (Posada \& Crandall 1998) was used to select the best model of DNA substitution for the Maximum Likelihood (ML) analyses according to the Akaike information criterion (AIC). For both genes, the GTR+I+G4 model was selected. The Maximum Likelihood analyses were done with Garli 0.951 (Zwickl 2006) under the General Time Reversible model with parameters for invariable sites and gamma-distributed rate heterogeneity. As outgroups, Pseudotraedriella (EF044311) and Eustigmatus magnus (AB280615), and Vischeria helvetica (HQ710612) were used for 18S rDNA and $r b c \mathrm{~L}$ analyses, respectively. A hundred bootstrap replicates were done for the ML and MP analyses.

${ }^{1}$ Bongiovani N, AM Martínez, C Popovich, D Constenla \& PI Leonardi. 2013. Efecto de la deficiencia de nitrógeno y la intensidad de luz sobre la productividad y composición lipídica en Nannochloropsis oceanica. HYFUSEN. $5^{\circ}$ Congreso Nacional- $4^{\circ}$ Congreso Iberoamericano. Hidrógeno y Fuentes Sustentables de Energía. p. 198. 
Table 1. Taxonomic data, collection site and GenBank accession number of taxa in the rbcL or 18S rDNA alignment / Datos taxonómicos, sitios de recolección y número de código de GenBank de los taxa de los alineamientos de rbcL y $18 \mathrm{~S}$ rDNA

\begin{tabular}{|c|c|c|c|c|}
\hline \multirow[t]{2}{*}{ Species } & \multirow[t]{2}{*}{ Strain } & \multirow[t]{2}{*}{ Collection Site } & \multicolumn{2}{|c|}{$\begin{array}{c}\text { GenBank Accession } \\
\text { Number }\end{array}$} \\
\hline & & & $r b c L$ & $18 \mathrm{~S}$ rDNA \\
\hline N. oceanica & CCALA 978 & Southwestern Ocean Atlantic Cost & $\begin{array}{l}\text { KF010153 } \\
\text { (this study) }\end{array}$ & $\begin{array}{l}\text { KF010154 } \\
\text { (this study) }\end{array}$ \\
\hline N. oculata & CCAP 849 & $\begin{array}{l}\text { Skate Point,Isle of Cumbrae, } \\
\text { Scotland, UK }\end{array}$ & $\mathrm{AB} 052286$ & - \\
\hline N. oculata & CCMP525 & $\begin{array}{l}\text { Skate Point, Isle of Cumbrae, } \\
\text { Scotland, UK }\end{array}$ & HQ710609 & AF045044 \\
\hline N. oculata & CCMP533 & $\begin{array}{l}\text { Lake of Tunis, Tunesia, North } \\
\text { Africa }\end{array}$ & - & AY045045 \\
\hline N. granulata & MBIC10054 & $\begin{array}{l}\text { Pacific Ocean, } 32^{\circ} 12^{\prime} \mathrm{N}, 147^{\circ} 23^{\prime} \\
\text { E }\end{array}$ & $\mathrm{AB} 052280$ & $\mathrm{AB} 052272$ \\
\hline N. granulata & BDH02 & Unknown & $\begin{array}{c}\mathrm{KC} \\
128502\end{array}$ & $\mathrm{KC} 128500$ \\
\hline N. granulata & CCMP1662 & Skagerrak, North Sea & - & AF045041 \\
\hline N. granulata & & Skagerrak, North Sea & & NGU38903 \\
\hline N. limnetica & KR1998 & $\begin{array}{l}\text { Arrowodd National Wildlife } \\
\text { Refuge, Itasca Lake Park, } \\
\text { Minessota, USA }\end{array}$ & DQ977729 & - \\
\hline N. limnetica & JL1125 & $\begin{array}{l}\text { Arrowodd National Wildlife } \\
\text { Refuge, Itasca Lake Park, } \\
\text { Minessota, USA }\end{array}$ & DQ977730 & - \\
\hline N. limnetica & DML1114 & $\begin{array}{l}\text { Arrowodd National Wildlife } \\
\text { Refuge, Itasca Lake Park, } \\
\text { Minessota, USA }\end{array}$ & DQ977740 & - \\
\hline N. limnetica & AS39 & $\begin{array}{l}\text { Arrowodd National Wildlife } \\
\text { Refuge, Itasca Lake Park, } \\
\text { Minessota, USA }\end{array}$ & DQ977741 & DQ977726 \\
\hline N. limnetica & AS2168 & $\begin{array}{l}\text { Arrowodd National Wildlife } \\
\text { Refuge, Itasca Lake Park, } \\
\text { Minessota, USA }\end{array}$ & DQ977739 & - \\
\hline N. limnetica & SAG1899 & $\begin{array}{l}\text { Lake Roter See, Mecklenburg- } \\
\text { Vorpommern, Germany }\end{array}$ & AM421006 & AF251496 \\
\hline N. limnetica & JL24 & $\begin{array}{l}\text { Arrowodd National Wildlife } \\
\text { Refuge, Itasca Lake Park, } \\
\text { Minessota, USA }\end{array}$ & - & DQ977727 \\
\hline N. gaditana & MBIC10118 & Shell Beach, Australia & AB052279 & AB052269 \\
\hline N. gaditana & MBIC10123 & Monkey Mia, Australia & $\mathrm{AB} 05273$ & AB052271 \\
\hline N. gaditana & MBIC10418 & $\begin{array}{l}\text { Atlantic Ocean, Cape Town, } \\
\text { South Africa }\end{array}$ & AB052735 & AB052271 \\
\hline$N$. gaditana & $\begin{array}{c}\text { Ferrara \& } \\
\text { Andreoli } 2004\end{array}$ & Comachio Lagoon, Ferrara, Italy & - & AF133819 \\
\hline N. gaditana & IVP & Unknown & - & AB473733 \\
\hline N. gaditana & $\begin{array}{l}\text { CCAP849/5- } \\
\text { CCMP1775 }\end{array}$ & Cadiz Bay, Cadiz, Spain & - & AF067957 \\
\hline N. gaditana & CCMP526 & Lagune di Quadilia, Morocco & - & AF045037 \\
\hline N. gaditana & $\mathrm{B}$ & Unknown & - & JF444989 \\
\hline N. gaditana & $\begin{array}{l}\text { CCAP849/5- } \\
\text { CCMP1775 }\end{array}$ & Cadiz Bay, Cadiz, Spain & - & AF045036 \\
\hline N. salina & CCAP849/2 & $\begin{array}{l}\text { Skate Point, Isle of Cumbrae, } \\
\text { Scotland, UK }\end{array}$ & AB052288 & AF045046 \\
\hline N. salina & MBIC10063 & Pacific Ocean, $41^{\circ} 28^{\prime} \mathrm{N}, 146^{\circ} 57^{\prime} \mathrm{E}$ & AB052287 & AB052278 \\
\hline N. oceanica & MBIC10179 & Red Sea, Eilat, Israel & $\mathrm{AB} 052283$ & AB052275 \\
\hline N. oceanica & MBIC10176 & Mediterranean Sea, Haifa, Israel & $\mathrm{AB} 052272$ & AB052274 \\
\hline N. oceanica & MBIC10426 & Red Sea, Eilat, Israel & $\mathrm{AB} 052284$ & AB052276 \\
\hline N. oceanica & MBIC 10440 & Red Sea, Eilat, Israel & AB052285 & AB052277 \\
\hline N. oceanica & MBIC 10090 & Pacific Ocean, Off Sanriku, Japan & $\mathrm{AB} 052281$ & AB052273 \\
\hline N. oceanica & LAMB001 & Unknown & HQ201773 & - \\
\hline N. oceanica & EUS001 & Unknown & - & HQ710567 \\
\hline N. oceanica & CCAP211/46 & Kuwait & - & AF045034 \\
\hline N. oceanica & CCAP211/78 & Unknown & - & AF045035 \\
\hline Nannochloropsis sp.1 & CCMP531 & Qingdao, China & - & U41094 \\
\hline Nannochloropsis sp.2 & CCMP505 & Morehead City, USA & - & U41050 \\
\hline Nannochloropsis sp. & UTEX2379 & Unknown & - & AY560119 \\
\hline
\end{tabular}




\section{RESULTS AND DISCUSSION}

Cells were spherical, with diameters of 2-3 $\mu \mathrm{m}$ and 3-5 $\mu \mathrm{m}$ under exponential and stationary growth phases, respectively. Light microscopic observations showed a smooth cell wall, a parietal chloroplast and an eyespot that was always present (Fig. 1). Cell dimensions of the isolate under study agree with the dimensions indicated for other strains of $N$. oceanica (Suda et al. 2002, Cao et al. 2013). However, the eyespot, which was constantly present in the algal strain under study and also in some cells of $N$. oceanica var. sinensis (Cao et al. 2013), was rarely observed by Suda et al. (2002). Our previous ultrastructural study showed that the cells of $N$. oceanica CCALA978 had a nucleus, a single parietal chloroplast and a thick cell wall (Bongiovani et al. 2013a). In this strain, the cell wall papilla and the pyrenoid-like structure described in $N$. oceanica and other species of Nannochloropsis by Suda et al. (2002) and Cao et al. (2013) were not observed. These authors did not find morphological traits to distinguish among $N$. granulata, $N$. salina, $N$. gaditana and $N$. oceanica by means of light microscopy or transmission electron microscopy.

Sequences for $18 \mathrm{~S}$ rDNA and $r b c L$ genes were used to identify several microalgal species and in particular to differentiate species of Nannochloropsis (Karlson et al. 1996, Krienitz et al. 2000). Here, the molecular studies based on 2 genes allowed us to identify the isolated strain CCALA978 as $N$. oceanica. The gene sequences for the strain were highly similar (100\% for $18 \mathrm{~S}$ rDNA and $99.7 \%$ for $r b c L$ ) to other strains of $N$. oceanica isolated from different marine habitats (Table 1). The intraspecific variation for the gene $r b c L$ within the species $N$. oceanica (100\% for $18 \mathrm{~S}$ rDNA and $99.7-100 \%$ for $r b c L$ ) was comparable to that of other species of the genus (99.8$99.9 \%$ identity within $N$. limnetica and $98.6-100 \%$ within $N$. gaditana). The phylogenetic analyses based on the rbcL (Fig. 2) and 18S rDNA (Fig. 3) genes resulted in a similar topology separating 2 main clades: $N$. oculata $+N$. oceanica $+N$. limnetica $+N$. granulata and $N$. gaditana $+N$. salina with high bootstrap support values. This result was also observed by Andersen et al. (1998), Krienitz et al. (1996) and Vieler et al. (2012) based on 18S rDNA; by Suda et al. (2002) and Cao et al. (2013) based on $18 \mathrm{~S}$ rDNA and $r b c L$; and by Wang et al. (2014) based on 1085 single-copy nuclear orthologous gene sets. This topology is consistent with a morphological difference between the 2 main clades. Species within the group of $N$. gaditana $+N$. salina are cylindrical in shape, while cells

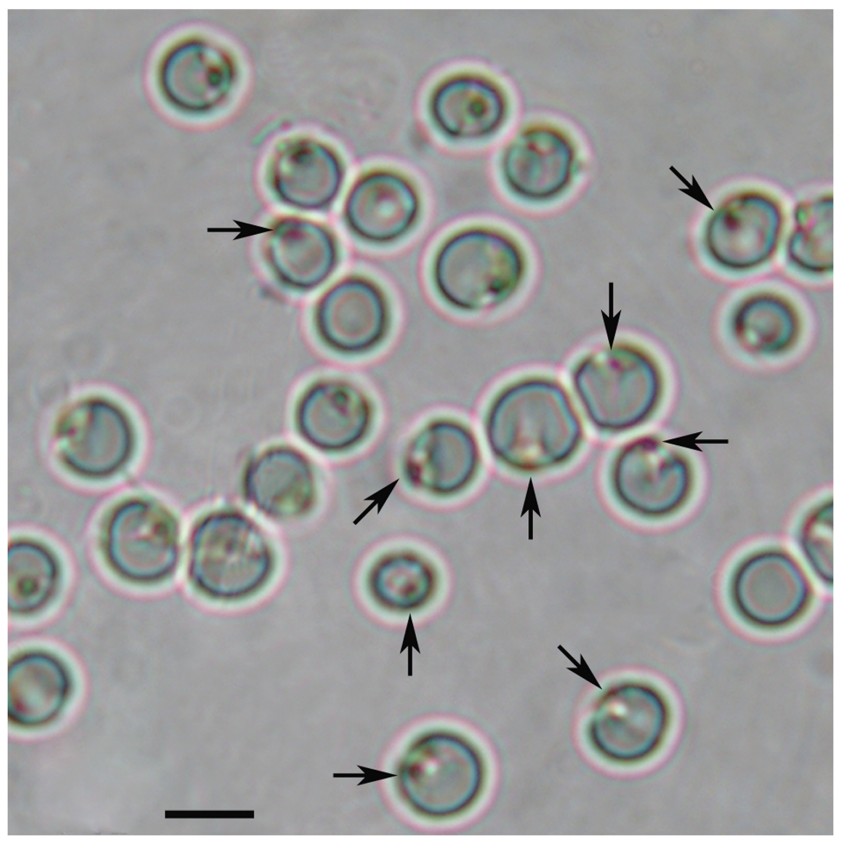

Figure 1. Light micrograph of Nannochloropsis oceanica. Arrows indicate the eyespot.

Scale bar $=3 \mu \mathrm{m} /$ Micrografía óptica de Nannochloropsis oceanica. Las flechas indican el estigma. Barra de escala $=3 \mu \mathrm{m}$ 


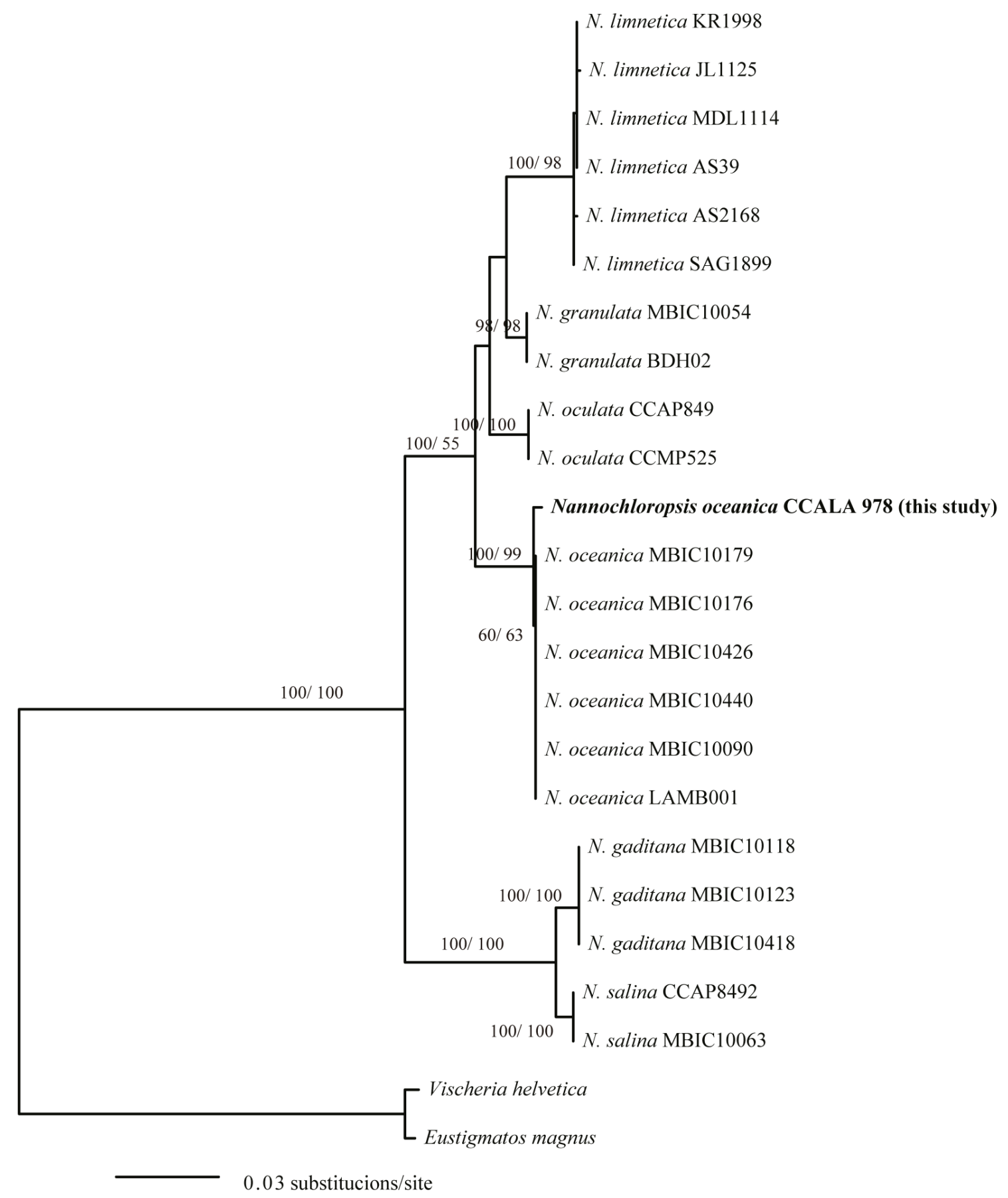

Figure 2. Maximum Likelihood (ML) phylogenetic tree based on the chloroplast-encoded rbcL (1389 nt) using Garli under the GTR $+1+G 4$ model selected by JM odelTest. Maximum Parsimony (MP) analyses were done with PAUP*4b10. Bootstrap values (100 replicates) from MP (left) and ML analysis (right) are provided when $>50 \%$ / Árbol filogenético bajo el criterio de Máxima Verosimilitud (ML) basado en el gen cloroplastídico rbcL (1389 nt) usando Garli con el modelo GTR+I+G4 seleccionado por JModelTest. Los análisis bajo el criterio de Máxima Parsimonia (MP) fueron realizados con PAUP*4b10. Los valores de soporte estadístico (100 réplicas) bajo MP (izquierda) y bajo ML (derecha) se encuentran indicados $\mathrm{si}>50 \%$ 


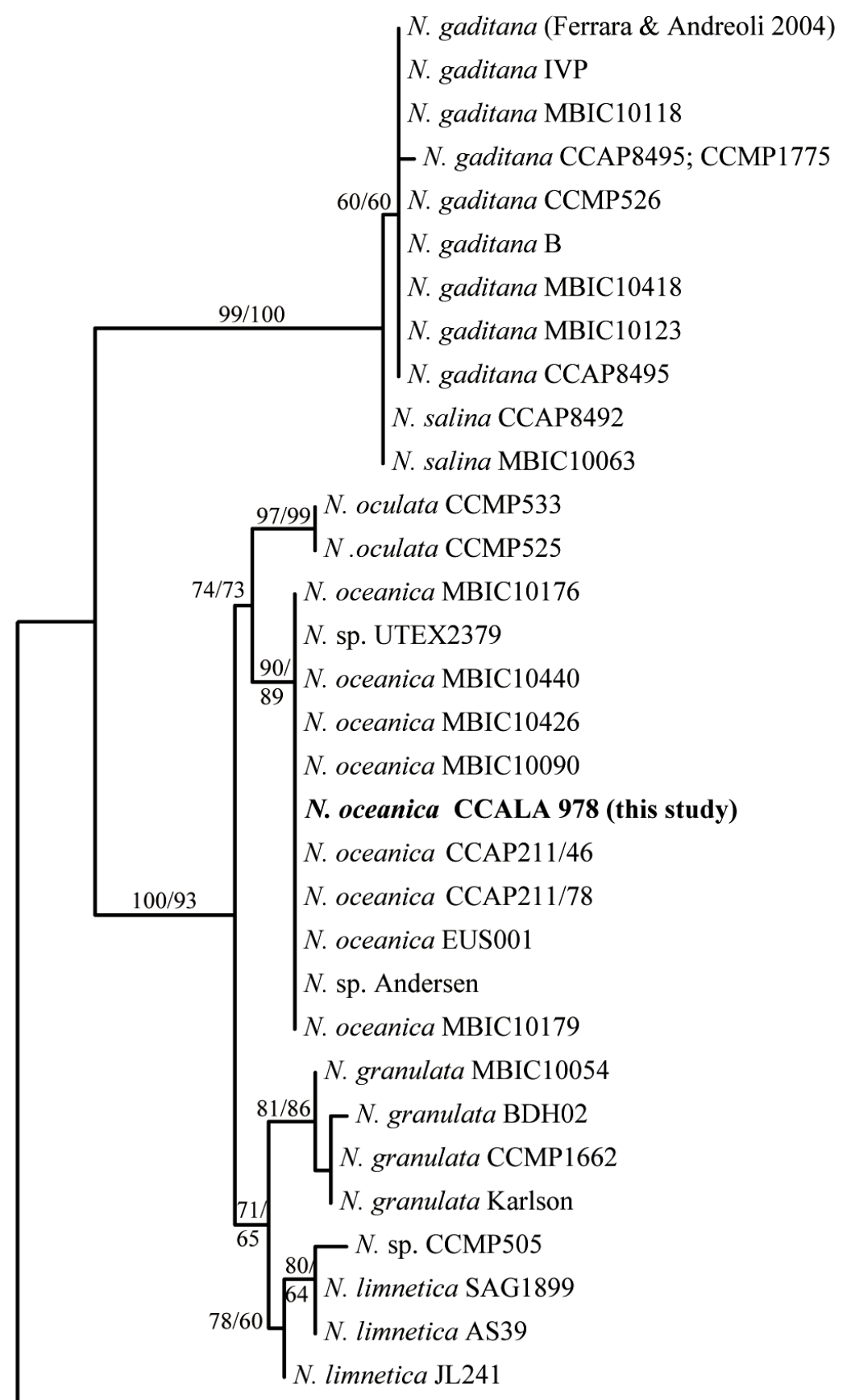

Pseudotetraedriella

0.0030 substitutions/site

Figure 3. Maximum Likelihood phylogenetic tree based on the nuclear gene $18 \mathrm{~S}$ rDNA (1792 nt) using Garli under the GTR+1+G4 model selected by JModelTest. Maximum Parsimony (MP) analyses were done with PAUP*4b10. Bootstrap values (100 replicates) from MP (left) and ML analysis (right) are provided when $>\mathbf{5 0} \%$ / Árbol filogenético bajo el criterio de Máxima Verosimilitud (ML) basado en el gen nuclear rDNA (1792 nt) usando Garli con el modelo GTR+1+G4 seleccionado por JModelTest. Los análisis bajo el criterio de Máxima Parsimonia (MP) fueron realizados con PAUP*4b10. Los valores de soporte estadístico (100 réplicas) bajo MP (izquierda) y bajo ML (derecha) se encuentran indicados si >50\% 
in species of the other clade are spherical to oval (Hibberd 1981, Lubian 1982, Karlson et al. 1996).

Microalgae exhibit environmental-tolerance ranges that are species-specific. Thus, a correct identification at species level ensures appropriate conditions to achieve a profitable and successful culture at large scale. In this study, an appropriate identification of a South American oleaginous microalgal strain of Nannochloropsis oceanica (CCALA 978) contributes to standardize processes towards biodiesel production.

\section{ACKNOWLedgments}

This study was supported by grants from Consejo Nacional de Investigaciones Científicas y Técnicas de la República Argentina (CONICET), PIP 112-201101-00208, Agencia Nacional de Promoción Científica y Tecnológica, PICT 2010-0959 and PICT 2008-277 and Secretaría de Ciencia y Tecnología de la Universidad Nacional del Sur, PGI TIR. MVSP and PIL are researchers of the CONICET, Argentina.

\section{LITERATURE CITED}

Andersen R, R Brett, D Potter \& J Sexton. 1998. Phylogeny of the Eustigmatophyceae based upon 18S rDNA, with emphasis on Nannochloropsis. Protist 149: 61-74.

Bondioli P, L Della-Bella, G Rivolta, G Chini-Zittelli, N Bassi, L Rodolfi, D Casini, M Prussi, D Chiaramonti \& MR Tredici. 2012. Oil production by the marine microalgae Nannochloropsis sp. F\&M-M24 and Tetraselmis suecica F\&M-M33. Bioresource Technology 114: 567-672

Bongiovani N, C Popovich, AM Martínez, H Freije, D Constenla \& PI Leonardi. 2013. In vivo measurements to estimate culture status and neutral lipid accumulation in Nannochloropsis oculata CCALA 978: implications for biodiesel oil studies. Algological Studies 142: 3-16.

Cao S, X Zhang, X Fan, H Qiao, C Liang, D Xu, S Mou, W Wang \& N Ye. 2013. Phylogeny and characterization of Nannochloropsis oceanica var. sinensis var. nov. (Eustigmatophyceae), a new oleaginous alga from China. Phycologia 52: 573-577.

Carpinelli EC, A Telatin, N Vitulo, C Forcato, M D'Angelo, R Schiavon, A Vezii, GM Giacometti, T Morosinotto \& G Valle. 2013. Chromosome scale genome assembly and transcriptome profiling of Nannochloropsis gaditana in nitrogen depletion. Molecular Plant 6: 323-335.
Dong HP, E Williams, D Whang, X Zhang, R Hsia, A Jenck, R Halden, J Li, F Cheng \& AR Place. 2013. Responses of Nannochloropsis oceanica IMET1 to long-term nitrogen starvation and recovery. Plant Physiology 162: 1110-1126.

Fawley KP \& MW Fawley. 2007. Observations on the diversity and ecology of freshwater Nannochloropsis (Eustigmatophyceae) with descriptions of new taxa. Protist 158: 325-336.

Fawley M, K Fawley \& H Owen. 2005. Diversity and ecology of small coccoid green algae from Lake Itasca, Minnesota, USA, including Meyerella planktonica, gen. et sp. nov. Phycologia 44: 35-48.

Ferreira M, P Coutinho, P Seixas, J Fábregas \& A Otero. 2009. Enriching rotifers with 'premium' microalgae Nannochloropsis gaditana. Marine Biotechnology 11: 585595.

Gladu PK, G Patterson, GH Wikfors \& BC Smith. 1995. Sterol, fatty acid and pigment characteristics of UTEX 2341, a marine Eustigmatophyte identified previously as Chlorella minutissima (Chlorophyceae). Journal of Phycology 31: 774-777.

Guillard RRL. 1973. Division rates. In: Stein JR (ed). Handbook of phycological methods: Culture methods and growth measurements, pp 289-311. Cambridge University Press, Cambridge.

Hibberd DJ. 1981. Notes on the taxonomy and nomenclature of the algal classes Eustigmatophyceae and Tribophyceae (synonym Xanthophyceae). Botanical Journal of the Linnean Society 82: 93-119.

Hu J, D Wang, J Li, G Jing, K Ning \& J Xu. 2014. Genomewide identification of transcription factors and transcription-factor binding sites in oleaginous microalgae Nannochloropsis. Nature, Scientific Report 4: 5454-5464.

Hu Q, M Sommerfeld, E Jarvis, M Ghirardi, M Posewitz M Seibert \& A Darzins. 2008. Microalgal triacylglycerols as feedstocks for biofuel production: perspectives and advances. Plant Journal 54: 621-639.

Karlson B, D Potter, M Kuylenstierna \& R Andersen. 1996. Ultrastructure, pigment composition, and 18S rRNA gene sequence for Nannochloropsis granulata sp. nov. (Monodopsidaceae, Eustigmatophyceae), a marine ultraplankter isolated from the Skagerrak, northeast Atlantic Ocean. Phycologia 35: 253-260.

Krienitz L, D Hepperle, HB Stich \& W Weiler. 2000. Nannochloropsis limnetica (Eustigmatophyceae), a new species of picoplankton from freshwater. Phycologia 39: 219-227. 
Leonardi PI, C Popovich \& C Damiani. 2011. Feedstock for second- generation biodiesel: microalgae's biology and oil composition. In: Dos Santos-Bernardes MA (ed). Economic effects of biofuel production, pp. 318-346. InTech Publisher, Rijeka.

Li F, D Gao \& H Hu. 2014. High-efficiency nuclear transformation of the oleaginous marine Nannochloropsis species using PCR product. Bioscience, Biotechnology and Biochemestry 78: 812-817.

Li J, D Han, D Wang, K King, J Jia, L Wei, X Jing, S Huang, J Chen, Y Li, Q Hu \& J Xu. 2014. Choreography of transcriptomes and lipidomes of Nannochloropsis reveals the mechanisms of oil synthesis in microalgae. The Plant Cell 26: 1645-1665.

Li S, K Pan, B Zhu, X Ma, X Liangm \& G Yang. 2011. Molecular identification of a species in genus Nannochloropsis. Journal of Ocean University of China 10: 391-396.

Lubian L. 1982. Nannochloropsis gaditana sp. nov., una nueva Eustigmatophyceae marina. Lazaroa 4: 287-293.

Maruyama L, T Nakamura, T Matsubayashi, Y Ando \& T Maeda. 1986. Identification of the algae known as 'marine Chlorella' as a member of the Eustigmatophyceae. Journal of Phycology 34: 319-325.

Medlin L, HJ Elwood, S Stickeland \& ML Sogin. 1988. The characterization of enzimatically amplified eukaryotic 16Slike r RNA-coding regions. Gene 71: 491-499.

Pal D, I Khozin-Goldberd, Z Cohen \& S Boussiba. 2011. The effect of light, salinity and nitrogen availability on lipid production by Nannochloropsis sp. Applied Microbiology and Biotechnology 90: 1429-1441.

Pal D, I Khozin-Goldberg, S Didi-Cohen, A Solovchenko, A Batushanky, Y Kaye, N Sikron, T Samani, A Faut \& S Boussiba. 2013. Growth, lipid production and metabolic adjustments in the euryhalline eustigmatophyte Nannochloropsis oceanica CCALA 804 in response to osmotic downshift. Applied Microbiology Biotechnology 97: 8291-8306.

Posada D \& K Crandall. 1998. ModelTest: testing the model of DNA substitution. Bioinformatics 14: 817-818.

Pruvost J. 2011. Cultivation of algae in photobioreactors for biodiesel production. In: Pandey A, C Larroche, SC Picke, CG Dussap \& E Gnansounou (eds). Biofuels: Alternative feedstocks and conversion processes, pp. 439-461. Elsevier, Amsterdam

Radakovits R, R Jinkerson, S Fuertenberg, H Tae, R Settlage, L Boore \& M Posewitz. 2012. Draft genome sequence and genetic transformation of the oleaginous alga Nannochloropsis gaditana. Nature Communication 3: 686.
Renaud S, D Parry, L Thinh, C Kuo, A Padovan \& N Sammy. 1991. Effect of light intensity on the proximate biochemical and fatty acid composition of Isochrysis sp., and Nannochloropsis oculata for use in tropical aquaculture. Journal of Applied Phycology 3: 347-356.

Rodolfi L, G Chini-Zittelli, N Bassi, G Padovani, N Biondi, G Bonini \& M Tredici. 2009. Microalgae for oil: strain selection, induction of lipid synthesis and outdoor mass cultivation in a low cost photobioreactor. Biotechnology and Bioengineering 102: 100-112.

Sforza E, A Bertucco, T Morosinotto \& G Giacometti. 2012. Photobioreactor for microalga growth and oil production with Nannochloropsis salina: from lab-scale experiments to large-scale design. Chemical Engineering Research and Design 90: 1151-1158.

Simionato D, E Sforza, E Corteggiani, A CarpinelliBertucco, GM Giacometti \& T Morosinotto. 2011. Acclimation of Nannochloropsis gaditana to different illumination regimes: Effects on lipids accumulation. Bioresource Technology 102: 6026-6032.

Simionato D, MA Block, N La Rocca, J Jouhet, E Meréchal, G Finazzi \& T Morosinotto. 2013. The response of Nannochloropsis gaditana to nitrogen starvation includes de novo biosynthesis of triacylglicerols, a decrease of chloroplast galactolipids, and reorganization of the photosynthetic apparatus. Eukaryot Cell 12: 665-676.

Solovchenko A, A Lukyanov, O Solovchenko, S DihiCohen, S Boussiba \& I Khozin-Goldberg. 2014. Interactive effects of salinity, high light, and nitrogen starvation of fatty acid and carotenoids profiles in Nannochloropsis oceanica CCALA 804. European Journal of Lipid Science Technology 116: 635-644.

Starkenburg SR, KJ Kwon, RK Jha, C McKay, M Jacpbs, O Chertkov, S Twary, G Rocap \& RA Cattolico. 2014. A pangenomic analysis of the Nannochloropsis organellar genomes reveals novel genetic variation in key metabolic genes. BMC Genomic 15: 212- 233.

Suda S, M Atsumi \& H Miyashita. 2002. Taxonomic characterization of a marine Nannochloropsis species, $N$. oceanica sp. nov. (Eustigmatophyceae). Phycologia 41: 273279.

Sukenik A, Y Carmeli \& T Berner. 1989. Regulation of fatty acid composition by irradiance level in the Eustigmatophyte Nannochloropsis sp. Journal of Phycology 25: 686-692.

Swofford D, G Olsen, P Waddell \& D Hillis. 2002. PAUP*. Phylogenetic analysis using parsimony (and other methods).Version 4. Sinauer Associates, Sunderland. 
Tamura K, D Peterson, N Peterson, G Stecher, M Nei \& S Kumar. 2011. MEGA 5: Molecular evolutionary genetics analysis using maximum likelihood, evolutionary distance, and maximum parsimony methods. Molecular Biology and Evolution 28: 2731-2739.

Van Vooren G, F Le Grand, J Legrand, S Cuiné, G Peltier \& J Pruvost. 2012. Investigation of fatty acids accumulation in Nannochloropsis oculata for biodiesel application. Bioresource Technology 124: 421-432.

Vieler A, G Wu, C-H Tsai, B Bullard, AJ Cornich, C Harvey, I-B Reca, C Thornburg, R Achawanantakun, CJ Buehl, MS Campbell, D Cavalier, KL Childs, TJ Clarck, R Deshpande, E Erickson, AA Ferguson, W Handee, Q Kong, X Li, B Lui, S Lundback, C Peng, RL Roston, Sanjaya, JP Simpson, A Terbuch, J Warakanont, S Zäuner, EM Farre, EL Hegg, N Jiang, M-H Kuo, Y Lu, KK Niyogi, J Ohlrogge, KW Osteryoung, Y ShacharHill, BB Sear, Y Sun, H Takahashi, M Yandell, S-H Shiu \& C Benning. 2012. Genome, functional and gen annotation and nuclear transformation of the heterokont oleaginous alga Nannochloropsis oceanica CCMP1779. PLOS Genetics 8: 1-25.
Wang D, K Ning, J Li, J Hu, D Han, D Wang, H Wang, X Zeng, X Jing, Q Zhou, X Su, X Chang, A Wang, W Wang, J Jia, L Wei, Y Xin, Y Qiao, R Huang, J Chen, B Han, K Yoon, RT Hill, Y Zohar, F Chen, Q Hu \& J Xu. 2014. Nannochloropsis genomes reveal evolution of microalgal oleaginous traits. PLOS Genetics 10: 1-13.

Wei L, Y Xin, D Wang, X Jing, Q Zhou, X Su, J Jia, K Ning, F Cheng, Q Hu \& J Xu. 2013. Nannochloropsis plastid and mitochondrial phylogenomes reveal organelle diversification mechanism and intragenus phylotyping strategy in microalgae. BMC Genomics 14: 534-551.

Zwickl DJ. 2006. Genetic algorithm approaches for the phylogenetic analysis of large biological sequence datasets under the maximum likelihood criterion. $\mathrm{Ph} \mathrm{D}$ dissertation, University of Texas, Austin, 115 pp. <http://repositories.lib. utexas.edu/handle/2152/2666> 